\title{
Exploring the Potential of Silviculture Agroforestry Regime as a Compatible Management in Southern Gunung Merapi National Park, Java, Indonesia
}

\author{
Priyono Suryanto (Corresponding author) \\ Faculty of Forestry, Gadjah Mada University, Yogyakarta, Indonesia \\ Tel: 62-274-550-542Ｅ-mail: psuryanto@ugm.ac.id \\ Mohd.Zaki Hamzah \\ Faculty of Forestry, Universiti Putra Malaysia, Selangor, Malaysia
}

Azmy Mohamed

Faculty of Forestry, Universiti Putra Malaysia, Selangor, Malaysia

Moh.Azani Alias

Faculty of Forestry, Universiti Putra Malaysia, Selangor, Malaysia

Nawari

Postgraduate Student, Faculty of Math and Natural Science

Gadjah Mada University, Yogyakarta, Indonesia

Wiratno

General Directorate of Forestry Protection and Nature Conservation

Ministry of Forestry, Indonesia

Received: November 9, 2010

Accepted: November 29, 2010

doi:10.5539/jsd.v4n3p81

\begin{abstract}
Silviculture Agroforestry Regime (SAR) is a compatible management model between the local community agroforestry with the intensive buffer zone and Gunung Merapi National Park (GMNP) through forest rehabilitation and renewal zonation system. The aims of this study: to assess the prospects of SAR among the stakeholders, i.e. the local community, the government and the researchers, as well as the challenges on its implementation. This study employed the SWOT analysis (i.e. strengths, weaknesses, opportunities and threats), synergized with the Analysis of Hierarchy Process (AHP) approach to quantitative the potential of SAR. The results revealed that SAR has a high potential for implementation in GMNP as a compatible management approach. In accordance with the stakeholders' perception, the strengths and opportunities outweigh the model's weaknesses and threats. SAR is potential for encouraging prospective buffer zone with intensive agroforestry management and also for accelerating forest rehabilitation and renewal zoning system of GMNP. Nonetheless, the implementation of SAR must be integrated with various strategies, for instance, the capacity building, documentation process and outcome, participative monitoring and evaluation, back up policy, experimental plot, compensation programme and skill improvement of silviculture agroforestry. Hence, SAR is serving as a "window opportunity" for learning model that includes the reference outside the national park as a promising buffer zone for developing this new Indonesia's national park, which avoids the image of 'paper park'.
\end{abstract}

Keywords: Silviculture agroforestry, Compatible management, National park, Stakeholder, SWOT-AHP 


\section{Introduction}

One of the models for protected area which is gaining rapid popularity in Indonesia is national park. At present, there are more than 50 new national parks, which were established since 2004 (Ministry of Forestry-Indonesia, 2006) and need to follow the technological innovation that is adaptive with specific locations (Sayer, 2001). The innovation management of national park must synergize with local community interest. The development and management of a protected area must focus on locally driven or people-centered and not the project oriented (Snelder and Lasco, 2008). Besides that, they should also strengthen the conservation function and the contextualization with the outside forest, or called the forestry community and agroforestry (FAO, 2006). In this effort, the prospective management needs the learning scheme in the national park or lessons for the acquisition of the best practice.

In this scheme agroforestry have an important position to accelerate prospective management in Indonesia national park. Agroforestry offers important livelihood benefits (World Bank, 2005). It is as a smallholder tree growing to mitigate the pressure on remaining forest resources and safe-guard ecological and socio-economic sustainability (FAO 2005, 2006). Agroforestry has also helped in reducing the dependency of the local farmers on national parks (Murniati et al., 2001). More recently, the role of agroforestry in mitigating climate change primarily through carbon sequestration has also been highlighted (IPCC, 2000, 2007).

Gunung Merapi National Park (GMNP), as a new management (Ministry of Forestry-Indonesia, 2004) for Merapi forest, has a long historical relationship with the local community. Markedly, the pattern of relationship between the GMNP management and the local community is still a contradictory situation. The existing local community that has intervened through harvesting the grass stock in the national park areas is perceived as a lose-win situation. On the other hand, in the perspective of formal legal Indonesian national park principle with the renewal of zonation system that prohibits the local community to harvest grass in GMNP is viewed as a win-lose situation. Based on these situations, breaking the relationship in GMNP can be done by employing strategies that could empower the farmers economically and promote sustainable agroforestry intensification using efficient, effective and affordable silviculture agroforestry technologies. Recently, the local community has been trying to regain the rights over the local resources and establish various forms of community-based resource management (Ferrari, 2006).

The agroforestry management in the surrounding areas of GMNP is the key element to redesign the zonation system in accordance to Indonesian national park principle. The directions in agroforestry research should (Nair, 1998) 'build bridges' from the past (examination), through the present (evaluation) and to the future (prognosis). Based on this, GMNP needs an innovative compatible scheme that will focus on the agroforestry regime (Suryanto et al., 2011) called Silviculture Agroforestry Regime (SAR). SAR, through intensive agroforestry, can be implemented for increasing the productivity in the surrounding southern of GMNP as well as the buffer zone management that is compatible with GMNP forest rehabilitation and renewal of zonation system. There are five SAR models, labelled as SAR1, SAR2, SAR3, SAR4 and SAR5 that have the ability to balance the agroforestry management, decrease the local community intervention and increase the biodiversity level in GMNP (Suryanto et al., 2011).

SAR supported by typology agroforestry surrounding GMNP (Suryanto et al., 2010a), the impact of local community on grass stock and the scheme for forest rehabilitation and also renewal zoning system of GMNP (Suryanto et al., 2010b). The eruption of Mount Merapi in 2006 gives unique information about lava which disturbed Kaliadem recreation park which has recently become an alternative promising location for tourism. Thus, succession information can used to support and strengthen Merapi lava tour viz., species diversity on early stage succession (Suryanto et al., 2010c), the species dynamic (Suryanto et al., 2010d) and the potential of pioneer species (Acacia decurrens) growth performance and standing stock that promising local community on supporting woodfuel (Suryanto et al., 2010e).

At the same time, there has been a rapid increase in the national park understanding of how such area should be managed more prospectively. In the transition situation from forest conservation to GMNP management, SAR is a compatible management and fundamental innovation that can accelerate the collaborative approach in that area. SAR is positioned as an innovative approach to ovoid 'conservation in a vacuum' on early GMNP management. In addition, its schemes have the potential to turn "win-lose" or "lose-win" situation into a "win-win" situation. Hence, this study aimed to assess the potential and challenges of SAR among the stakeholders, i.e. the local community, the government and the researchers surrounding GMNP by utilising the SWOT (strengths, weaknesses, opportunities, and threats) - AHP (analytic hierarchy process) approach. 


\section{Methods}

\subsection{Identification of stakeholders}

This study identified three leaders, representing the local farmers who owned lahan andil (i.e. the state forest lands that are temporarily cultivated by the forest farmers for agricultural crops on GMNP). This study considered the opinions of these three individuals as the key local leaders and the key persons that had experiences on the local community on the dynamic relationship with Mount Merapi forests. Based on the theory of diffusion of innovations, it concludes that these leaders reflect the opinion preferences of masses which hold the centrist views in rural agricultural communities (Rogers et al., 1988). On the other hand, the government was represented by the GMNP manager, i.e. PEH (pengendali ekologi hutan/the controller forest ecology), while the Ministry of Forestry was represented by the Director of the modelling protected area. Conversely, the researchers from the university and the NGO personnel that conducted activities in the surrounding areas of southern GMNP were the third category of the stakeholders.

\subsection{Classification of decisive factors}

The reviews on the prospects and challenges of SAR with the SWOT-AHP approach. One of the main limitations of SWOT is the importance of each factor cannot be measured quantitatively (Pesonen et al., 2000). Providing quantitative measure of importance of each factor on decision-making is used combination between SWOT and AHP (Kurttila et al., 2000; Saaty and Vargas, 2001; Ananda and Herath, 2003).

The early step was conducted using the SWOT-AHP analysis with the formulating criteria on all aspects, namely; strengths, weaknesses, opportunities and threats. Identification and classification of critical decisive factors were accomplished using the comparative study. Besides that, the identification was also supported by the literature review of the focus group discussions with the local community and the interviewer. This includes identifying key stakeholders involved in the decision problem, the classification of key factors influencing decisions and evaluation of factors using the SWOT-AHP framework (Kurttila et al., 2000; Ananda and Herath, 2003). After preparing the preliminary list of the decisive factors, it was then categorized into 12 major factors; three of which were placed in each SWOT group (as mentioned in Figure 1).

To keep the pair-wise comparisons at a manageable level, this study worked with three key factors in each SWOT category. The result of outweigh on the stakeholders was calculated with the average relative weigh of every aspect that was then continued with the consistency test. The calculation process was conducted by arranging the matrix pair-wise comparison in each criterion as follows (Kurttila et al., 2000):

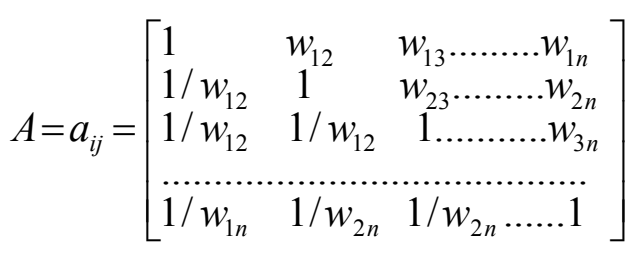

where $A$ is the pair-wise comparison, $w_{i j}$ is the weigh relative of element $i$ to element $j$ and $n$ is the matrix size. Then, adding operation was done in every column and resulted in matrix B:

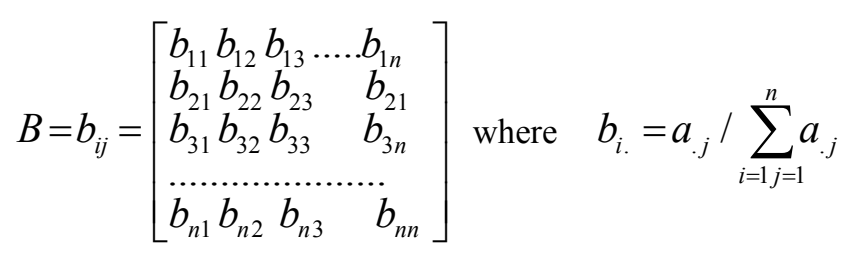

The relative weigh of every element $\left(\mathrm{w}_{\mathrm{i}}\right)$ was calculated using the following formula:

$$
\mathrm{w}_{\mathrm{i}}=\sum_{\mathrm{j}=1}^{\mathrm{n}} \mathrm{b}_{\mathrm{j}} / \mathrm{n}
$$

Then, the eigen value of each element $\left(\lambda_{i}\right)$ and eigen $\max \left(\lambda_{\max }\right)$ were calculated following this formula:

$$
\lambda_{\mathrm{i}}=\left(\sum_{\mathrm{i}=1 \mathrm{j}=1}^{\mathrm{n}} \mathrm{a}_{\mathrm{j}} * \mathrm{w}_{\mathrm{i} .}\right) / \mathrm{w}_{\mathrm{i} .} \text { and } \lambda_{\max }=\sum_{\mathrm{i}=1}^{\mathrm{n}} \lambda_{\mathrm{i}} / \mathrm{n}
$$


Saaty (1977) demonstrated that $\lambda_{\max }$ is a necessary and sufficient condition for consistency. Inconsistency may arise when $\lambda_{\max }$ deviates from $\mathrm{n}$ due to inconsistent responses in pair-wise comparisons. Therefore, matrix A should be tested for the ratio consistency using the following formula:

$$
\mathrm{CR}=\mathrm{CI} / \mathrm{RI} ; \mathrm{CI}=\left(\lambda_{\max }-\mathrm{n}\right) /(\mathrm{n}-1)
$$

where $\mathrm{CR}$ is the consistency ratio, $\mathrm{CI}$ is the consistency index and $\mathrm{RI}$ is the random index (RI) generated for the random matrix of order n (Saaty, 1993; Mawapanga and Debertin, 1996). The general rule is that; CR $\leq 0.1$ should be maintained for the matrix to be consistent. The homogeneity of factors within each group, smaller number of factors in the group and better understanding of the decision problem would improve the consistency index (Saaty, 1993).

Estimating the overall factor priority scores was the third step. This required the derivation of a scale parameter for each SWOT group. The overall priority score of each factor was then computed as the product of the factor priority score (obtained in the second step) and the scale parameter. These overall priority scores can be analyzed and used in the decision-making process. In addition, the formulation strategy was based on the results of the SWOT-AHP analysis. The analysis was given by the high priority of each aspect of the group. The high priority aspects became the basis for the formulation strategy of SAR model implementation carried out through the comprehensive strategies; i.e. SO-strategy, WO-strategy, ST-strategy and WT-strategy. The key SWOT factors influencing SAR illustrated at Figure 1.

\section{Results}

The data obtained from three respondents were analyzed separately to derive factor priority and overall priority scores and weighted equally to estimate mean scores (Table 1). Factor priority scores demonstrate the relative importance of each factor within SWOT groups. The overall priority scores obtained by adjusting priority scores with scale parameters illustrate the relative importance of each factor across all SWOT groups. The mean scores reflect the aggregated preferences of respondents to SAR implementation. The description of every stakeholder is explained as follows.

\subsection{The local community}

Generally, the local community valued SAR and which state that the implementation reference of pro poor conservation especially the national park as a win-win solution $\left(\mathrm{S}_{2}\right)$ as the most important strength, with the priority score of 0.6291 (Table 1). Meanwhile, the second most important strength factor stated the local community was the potential success of pioneer species (i.e. A. decurrens) as the supporting local energy stock and species diversity for the attraction of Merapi lava tour $\left(\mathrm{S}_{3}\right)$, which gave the priority score of 0.2545 . These findings indicate that the local community wanted to innovate the income generating the tourism especially the Merapi lava tour with supported succession information. Besides, the pioneer species (A. decurrens) also has a standing potential for the local's energy stock.

There are two opportunities of nearly equal magnitude; firstly, the collaborative model that becomes an important mandate in Indonesia's national park management $\left(\mathrm{O}_{2}\right)$, which gave the priority score of 0.5049 , and secondly, the increasing demand of specific silviculture technology for the protected area $\left(\mathrm{O}_{3}\right)$, that gave the priority score of 0.4091 . Thus, SAR is important as an innovation from the collaborative management national park. Conversely, in supporting the implementation of SAR, the most serious weakness that needs a full support from the stakeholders (W3) gave the score of 0.4426 . This respondent group also perceived that the government policy that may change at any time (T1) is a critical threat, which gave the factor priority score of 0.7239 (Table 1).

The local community's responses obtained from the across-group analysis revealed that the opportunity group was highly influential in SAR compared with the other three SWOT groups. The priority score representing the opportunity group was 0.3319 (Table 1), followed by the threats, i.e. 0.2772 , the strengths, i.e. 0.2470 , and the weaknesses, i.e. 0.1439 . The overall priority score of each factor was computed using the factor and group priority scores. Precisely, the overall priority score was 0.1554 . Meanwhile, as for the implementation reference of pro poor conservation especially the national park with win-win solution $\left(\mathrm{S}_{2}\right)$, the factor priority score was 0.629 , whereas for the strength group priority score, it was 0.2470 .

The overall priority scores are presented in a graphical framework as shown in Figure 2. The values in each quadrant must be interpreted in absolute terms. In Figure 2, the cumulative score of each SWOT group indicates its relative importance compared to other groups. For this respondent group, the opportunity factors had about $28 \%$ 
influence on the SAR model. On the other hand, the weakness factors revealed about $14 \%$ impact on the SAR model of acceptability.

\subsection{The government}

From within-group analysis of government, it was revealed that the forest rehabilitation and the renewal zonation systems of GMNP are compatible with the agroforestry management on the surrounding areas of GMNP as a buffer zone intensive $\left(\mathrm{S}_{1}\right)$. It is the most important strength in SAR acceptability, giving the priority score of 0.6518 (Table 1). On the other hand, the most important opportunity factor as perceived by government is the collaborative model, which has become an important mandate in Indonesia's national park management $\left(\mathrm{O}_{2}\right)$, giving the priority score of 0.6521 . Meanwhile, the most influential weakness factor as perceived by government is $\mathrm{W}_{3}$, with the priority score of 0.4536 . Finally, the two critical threats of nearly equal magnitude are the government policy which may change any time $\left(T_{1}\right)$ and the changing market orientation that encourages monoculture on the agroforestry system $\left(\mathrm{T}_{2}\right)$, giving the factor priority scores of 0.325 and 0.4031 , respectively.

The across-group analysis of the government preferences shows predominant influence of strength factors with a group priority score of 0.4063 followed by opportunity, threats and weakness with priority scores of 0.2719 , 0.2278 and 0.0746 , respectively (Table 1 and Figure 3 ). The overall priority score of each factor is computed using factor and group priority scores. For example, the overall priority score, 0.2648 , for forest rehabilitation and also renewal zonation systems of GMNP that compatible with agroforestry management on surrounding GMNP as a buffer zone intensive $\left(S_{1}\right)$ of its factor priority score $(0.6518)$ and strength group priority score 0.4063 . The overall priority scores are presented in graphical framework (Figure 3). In Figure 3, the cumulative score of each SWOT group indicates its relative importance compared to other groups. For this respondent, strength factors will have about a $41 \%$ influence on SAR model. Which opportunity i.e. $27 \%$ and threat i.e. $25 \%$. On the other hand, weakness factors are shown to have only about a 7\% opportunity impact on the SAR model acceptable.

\subsection{The researchers}

The analysis of the researchers' perception also indicates that the forest rehabilitation and the renewal zonation systems of GMNP are compatible with the agroforestry management on the surrounding areas of GMNP as a buffer zone intensive $\left(\mathrm{S}_{1}\right)$. It is the most important strength of SAR acceptability, giving the factor priority score of 0.4147 . Conversely, the most important opportunity factor as perceived by the researchers is the collaborative model, which has become an important mandate in Indonesia's national park management $\left(\mathrm{O}_{2}\right)$, giving the priority score of 0.5365 .

There are two most influential weakness factors as perceived by the researchers were $\mathrm{W}_{3}$ and $\mathrm{W}_{1}$ with the priority scores of 0.4536 and 0.3594 , respectively. Finally, the critical threat from the changing market orientation that encourages monoculture on the agroforestry system $\left(\mathrm{T}_{2}\right)$ gave the factor priority score of 0.4858 .

The across-group analysis of the researcher preferences shows predominant influence of strength factors with a group priority score of 0.3806 followed by opportunity, threats and weakness with priority scores of 0.2570 , 0.2278 and 0.1346 , respectively (Table 1 and Figure 4). The overall priority score of each factor is computed using factor and group priority scores. For example, the overall priority score, 0.1578 , for forest rehabilitation and also renewal zonation systems of GMNP that compatible with agroforestry management on surrounding GMNP as a buffer zone intensive $\left(\mathrm{S}_{1}\right)$ of its factor priority score $(0.4147)$ and strength group priority score 0.3806. The overall priority scores are presented in graphical framework (Figure 4). In Figure 10.4, the cumulative score of each SWOT group indicates its relative importance compared to other groups. For this respondent, strength factors will have about a $38 \%$ influence on SAR model. Which opportunity i.e. $26 \%$ and threat i.e. $23 \%$. On the other hand, weakness factors are shown to have only about a $13 \%$ opportunity impact on the SAR model acceptable.

Overall, the researchers stated that the zoning system reformation and rehabilitation, as well as the restoration of ecosystems that are compatible with the optimization of agroforestry as a buffer zone around the intensive TNGM had the highest weighting compared to other aspects. This means that the researchers believed that the existence of SAR is compatible to support the development of the national park management prospective.

Furthermore, SWOT provides a framework for delivering strategies based on the promising combination of the identified strengths, weaknesses, opportunities and threats. In particular, the SO-strategy includes strengthening the capacity building of the local community and the GMNP staff, information documentation, as well as the dissemination and scaling up of SAR. Conversely, the WO-strategy is utilized to establish the plot experiment of SAR and increase the silviculture agroforestry skills, whereas, the ST-strategy is used to shift the focus of 
enabling legislation for supporting SAR as an innovation of collaborative management and sustaining the local innovation with compensation development. Finally, the WT-strategy is employed to promote more equitable distribution of SAR benefits and build synergy between the technological change and the socio-economic, cultural and political dimensions of SAR.

\section{Discussion}

\subsection{Potential of SAR among the stakeholders}

The prospect based on the SWOT group as perceived by the local community, revealed that SAR has potential strengths and a huge opportunity to be implemented. Furthermore, SAR is a step for those who want to flee far from the conflict zone and to kick start a new compatible management between the local community and the national park. The local community's aspiration becomes an important component in SAR especially in the participation of GMNP management. The establishment and management of all categories of proper protected areas are evolving towards more focus following the aspirations and needs of the local people (Phillips, 2003). Besides, the highlight approach that is people-centred, roots in the objective of improving the people's livelihood and is locally driven. Moreover, it is a new model of "pro-poor conservation" (Barber, 2004).

The local community perceived that the SAR weaknesses are relatively less than the other aspects. However, the threat of policy that may change at any time was seen as a concern that may harm their interests from the GMNP region. In general, the SWOT analysis of the local community emphasized that it is the most important issue for the implementation of the SAR model in support of the policy clarity. Notably, SAR is a compatible management that builds synergy between the agroforestry intensive management and the ecosystem restoration of GMNP, which must be backed up by the legal policy. Having mentioned that, the policy can be improved through capacity building, legal counselling and government commitment. Supporting the poverty alleviation for forest-based communities requires a radical rethinking of forest policy (Larson and Ribot, 2007). In this case, recognizing appropriately the rights of the local people to participate in decision making is related to the implementation of SAR.

Still on the local community's perspective, SAR with its strengths integrated with the land use surrounding GMNP is compatible with the renewal zonation system and forest rehabilitation that has the opportunity to minimize the conflict by offering a win-win solution. In addition, Mount Merapi with a new management national park has many potential conflicts especially in the zonation system. Generally, the conflict to maintain the biodiversity sustainability needs has become the objective dispute less than the planning of zonation and demarcating zones to manage the stakeholders (Hanna et al., 2008). The existence of local community in the surrounding GMNP should be positioned as a part of the solution in the integrated conservation perspective of the local community. The community stage management regime fulfils the important prerequisite of the protected area, being "managed through other effective means" and not always necessarily "managed through legal means" (Wishitemi and Okello, 2003).

As Adams and Hulme (2001) note, the task for the protected areas is not replacing one governance paradigm with another, but rather finding the best combination of them by identifying the most of complementary roles and contributions of existing and new approaches. According to the government, with regards to the policy aspects and changes in the market orientation that encourage monoculture type in agroforestry systems, serious consideration is needed for successful implementation of the SAR model. Needless to say, the primary goal of most protected areas is to conserve the biological diversity and provide ecosystem services, and not to reduce poverty (Scherl et al., 2004). Nevertheless, enabling policies can facilitate the institutionalization of participatory approaches to SAR implementation.

The most important local community has shaped much of Mount Merapi over a millennia. Mountains are a vital basis of water, energy and biological diversity, and are important for the survival of the multi-faceted global ecosystems (Krauchi et al., 2000). Besides that, the local community's land uses, i.e. home garden, dry field and land village that are managed by the agroforestry system developed through livestock grazing have been dependent on GMNP for a long time. With this fact, the existing agroforestry becomes the key importance especially in maintaining the present biodiversity. Agroforestry de facto controls the poor farmers (Puri and Nair, 2004), thereby, the configuration agroforestry aids biodiversity conservation (Schroth et al., 2004).

Nevertheless, the fear of market orientation is a serious concern of government because it can be the main obstacle to success, where people tend to follow the market orientation. Strategies are aimed at some approaches to compatibles the goals concerning poverty, development and environment focus on the agricultural diversification and productive conservation (Perz, 2004). Moreover, conservation is not just an ecosystem but it 
is also about managing people. In addition, a large part of the protected areas programme is about empowering and assisting the people to manage themselves and the ecosystems (Barber, 2004).

It must be acknowledged that the protected areas cannot be viewed in isolation from the communities because the community-based approaches play a growing role as well (Brown and Mitchell, 2000). Furthermore, the GMNP manager perceived that the highest scores from the SAR model are the forest rehabilitation and the renewal zonation systems of GMNP, which are compatible with the management of agroforestry in the surrounding areas of GMNP as a buffer zone intensive $\left(\mathrm{S}_{1}\right)$. The existence of SAR as a compatible management depends on the levels and tradition cooperation and the levels of conflict between the stakeholders. On the other hand, compatibility depends on the power dynamics of the stakeholders represented in the policy maker (Spilsbury and Nasi, 2006). Therefore, the arrangement of innovation management of GMNP is based on the flexibility that is connected with partnership and community-based approaches. Land-use flexibility and buffer zones with areas adjoining to the protected areas with multiple land uses are tailored to serve both sustainable use and conservation goals (Barber, 2004).

The researcher believed that the collaboration model has become an important mandate in Indonesia's national park management, thus SAR is very prospective for implementation. Mindful of this, the $\mathrm{V}^{\text {th }}$ IUCN World Parks Congress is adopted as a principle following the statement: strengthen and expand protected areas that are co-managed by, for instance, the local communities, the government, the NGOs or the private sector as in the case of the surrounding protected areas (IUCN, 2003). In Indonesia, one of the most powerful ways that the government has supported conservation efforts is by involving multi-stakeholder participation in the management of the protected areas. Some proofs of the flagship success stories, with less well-known virtual examples, are Bunaken National Park and Komodo National Park (Purnomo, 2005). Thus, SAR existent can be added as a reference towards the innovative collaboration of the national park in Indonesia.

\subsection{Strategy implementation of SAR}

Strengthening the capacity building of the local community and GMNP staff has become an important SO-strategy. Besides, strengthening the capacity of the local agroforestry communities to continuously learn and experiment ways of improving their livelihood is also equally important. This strategy is set up in order to encourage cooperative learning between the local community and the GMNP staff. In a hierarchical approach, Sayer and Maginnis (2005) conclude that the ecosystem approach is replaced by the social learning concept of "we are learning together", whereas the sustainable forest management is slightly more open, which is based on the concept "we manage you participate". Meanwhile, as for sustaining the yields of forestry, Sayer and Maginnis (2005) mention that it is founded on the command and control concept of "we manage". Therefore capacity building for supporting SAR is very important through learning together among stakeholder. It is apart from increasing the skill level, also minimizes the mismatch and levels the playing of field-power sharing.

The other strategies include documenting information (i.e. process, output, and outcome) as well as disseminating and scaling up the design of SAR as a learning centre. Documentation is important for providing decision-support tools and information for enriching strategy development of SAR based on experience. In addition, disseminating and scaling up for the development of learning and extension mechanisms, information support to policy development, promoting networking and horizontal linkages in the implementation of SAR are important too.

Conversely, obstacles to the implementation of SAR include putting these new principles into practice, which is undeniably easier said than done. The scheme of conservation also takes place within the same constraints as other 'development' activities (Colchester, 2004). This SAR, as an integrative planning strategy, follows the implementation of monitoring and evaluating SAR participatively. In the integrative planning, it clearly states the long-term goals, objectives and continuous monitoring of the ecosystem (Brody, 2003).

The strategy for WO, i.e. the development of plot experiment of SAR in private land, is a pilot intensive agroforestry system. Meanwhile, in the GMNP area, it is a model of forest rehabilitation and a renewal zonation system. The establish plot is important to join the setting agenda for experimentation, technological development and evaluation, integration of technological components of SAR, assisting and piloting. Besides that, the plot is also crucial in promoting, supporting and instituting synergistic efforts in linking the production, value addition, marketing for prospective productivity and biodiversity agroforestry as well as GMNP ecosystem. This plot has become a reference for the development of compatible approach on the other regions of GMNP as a site based biodiversity.

McShane and Wells (2004) conclude that the system links the local community and the management of the protected areas with the site-based biodiversity conservation approach that offers a realistic prospect of success. 
Besides that, it provides the capacity for building support in instituting the link between the farmers and establishing support mechanisms for capacity development as a learning together. The concept of farmer-to-farmer outreach is to promote the installation of conservation buffer zone, that is popular as a "Farm Link" (Shelton et al., 2009). The learning scheme is followed by the building synergy between the technological agroforestry innovation and the silviculture regime for conservation.

On the other hand, the specific strategies for WO involve increasing the skills of silviculture agroforestry through organizations of courses, training, as well as the extension and programme facilitation of intensive agroforestry in the scope of empowering the local community. Moreover, the capacity building need for the local community surrounding GMNP is not entirely on the theoretical understanding, which has been mostly emphasized. Instead, the policies need to be focused on building the competence in silviculture agroforestry skills and technologies connected to the improvement of the on-farm productions. In addition, the capacity building policies are also set up to strengthen and promote the GMNP staff for silviculture conservation regime.

All of these confirm that the capacity building policies are needed to change the strategies and back tailored generation and transfer of skills, awareness creation and sensitization roles for both off-farm and on-farm value addition interventions. Yet, no single instrument or approach can overcome the barriers prevalent in the national park management, including SAR. However, a good enabling condition exists, whereby the effectiveness of the delivery or adaptation processes remain pivotal to successful innovation uptake and technology transfer (Spilsbury and Nasi, 2006).

Shifting the focus of enabling legislation for supporting SAR is an innovation collaborative management as a ST-strategy. This also includes establishing the support role mechanisms of collaborative management from the Ministry of Forestry, GMNP and the local government. Moreover, the changing of SAR legislation is supported by button up mechanism. Policy makers set the framework and create an enabling condition that does not only support the protection of biological diversity, but adapts, as mangers do, to emerging threats and opportunities (Barber et al., 2004). Enabling policies can facilitate the institutionalization of participatory approaches to implement SAR.

The ST-strategy is potential in sustaining the local innovation with compensation development. The compensation is more on the agroforestry with the payment of environmental services. In addition, the compensation scheme is carried out by the incentive programme from the Ministry of Forestry through GMNP or the local government support. The agroforestry system surrounding GMNP does not only support the productivity, but also maintains the conservation. Agroforestry is a miniature natural forest or artificial forest (Ashton and Montagnini, 2000). Therefore, it needs a silviculture strategy based on ecology that relates with agroforestry, which is one of the best trees outside the forest. Silviculture, in the stand level management, is transforming in the movement towards more "naturalness" (O'hara, 2001) with a new conceptual model that is "close-to-nature forestry" (Mlinsek, 1996).

Conversely, the term silviculture is inappropriate to use in any context other than that of timber production or should be developed timber production is not the objective (Guldin and Graham, 2007). Maintaining the biodiversity can be achieved through an adequate network of protected areas, which integrates conservation production and non-production functions (Parviainen and Frank, 2003). Based on this fact, agroforestry system surrounding the GMNP areas is suitable for special compensation in reducing poverty. For instance, the optimalisation of SAR is a potential based on tourism. Merapi lava tour and information succession are able to support and promote tourism. Needless to say, the national parks around the world have been recognized as important tourism and recreational resources for visitors (Buckley, 2000).

On the other hand, the WT-strategy promotes more equitable distribution of SAR benefits. Having mentioned that, SAR is designed to facilitate the access of resources for increasing the production and conservation aspect. In GMNP context, the local community with SAR model providing access, is given a certain limited use of resources, which enables the people to harvest in a non-destructive manner the natural resources such as medicinal plants, seeds and non-wood forest products under a permit system. Poverty is not only about lack of money, more broadly, it can be seen as the deprivation from the resources that are needed for dignified survival and secure livelihood (Kothari and Lockwood, 2006). Nevertheless, infrequently protected areas are designed specifically to reduce poverty, but this does not mean that they are isolated from sustainable development and the alleviation of poverty (Scherl et al., 2004). Therefore, SAR as a win-win solution between the local community and GMNP must be promoted to all the stakeholders, that is synergized with the development agenda. 
Meanwhile, the other strategy for WT is building the synergy between the technological change and the socio-economic, cultural and political dimensions of SAR. Mount Merapi with a new national park management on transition involves an iterative process of continuous improvement. The process will require an innovative regime, i.e. SAR is not supported by the government alone, but also by the local community and other stakeholders in general. The government has a total legal backup from disabling to enabling policies for SAR implementation.

In the development of SAR in other regions of GMNP, a far more targeted approach is required to exploit the comparative advantage of different resource management strategies in order to minimize the one-size-fits-all strategy (Sayer, 2001; Sayer and Maginnis, 2005). Because every site is different, therefore, the management will be unique too. Hence, the framework for assessing the overall progress is useful, but it should be secondary to the need to truly attune the local realities in terms of the local needs, constraints and opportunities (Sayer, 2001).

\section{Conclusion}

SAR follows the systematic conservation planning approach and reassesses the network periodically (Margules and Sarkar, 2007). Thus, comprehensive evaluation with the participation of all stakeholders will encourage SAR more prospectively. SAR has a high potential for implementation in GMNP as a compatible management approach. In accordance with the stakeholders' perception, the strengths and opportunities outweigh the model's weaknesses and threats. In addition, SAR is potential for encouraging prospective buffer zone with intensive agroforestry management and also for accelerating forest rehabilitation and renewal zoning system of GMNP. SAR is also prospective for innovating collaborative management in Indonesia national park, whereby it does not only maintain the biodiversity, but also the pro-poor target. Nonetheless, the implementation of SAR must be integrated with various strategies, for instance, the capacity building, documentation process and outcome, participative monitoring and evaluation, back up policy, experimental plot, compensation programme and skill improvement of silviculture agroforestry. Hence, SAR is a compatible management model between the national park and the local community - serving as a "window opportunity" for learning model that includes the reference outside the national park as a promising buffer zone for developing this new Indonesia's national park, which avoids the image of 'paper park'.

\section{References}

Adams, W. and Hulme, D. (2001). Changing narratives, policies and practices in Africa conservation. In African Wildlife and Livelihoods: the Promise and Performance of Community Conservation, ed. D.Hulme, and M.Murphree, pp 24-37.Oxford. James Currey.

Ananda, J. and Herath, G. (2003). The use of Analytic Hierarchy Process to incorporate stakeholder preferences into regional forest planning. Forest Policy and Economics 5:13-26.

Ashton, M.S. and Montagnini, F. (2000). A philosophical approach to silviculture in agroforestry. In The Silvicultural Basis for Agroforestry Systems, ed. M.S. Ashton, and F. Montagnini, pp. 1-6. CRC Press LLC.

Barber, C.V. (2004). Parks and people in a world of changes: governance, participation and equity. In Securing Protected Areas in the Face of Global Change: Issues and Strategie, ed. C.V. Barber, K.R. Miller, and M. Boness, pp. 97-134. IUCN, Gland, Switzerland and Cambridge, UK.

Barber,C.V., Bergst,B., Janetos, A.C., Scherr, S., and Wolcott, R.M. (2004). Understanding global change. In Securing Protected Areas in the Face of Global Change: Issues and Strategies, ed. C.V. Barber, K.R. Miller, and M. Boness, pp. 1-30. IUCN, Gland, Switzerland and Cambridge, UK.

Buckley, R. (2000). Neat trends: current issues in nature, eco- and adventure tourism. International Journal of Tourism Research 2:437-444.

Ferrari, M.F. (2006). Rediscovering community conserved areas in South-east Asia: peoples' initiative to reverse biodiversity loss. Parks 16(1) Community Conserved Areas.

Food and Agricultural Organization (FAO). (2006). Global Forest Resources Assessment 2005 - Progress Toward Sustainable Forest Management. FAO Rome, Italy.

Food and Agricultural Organization (FAO). (2005). State of the World's Forests 2005. FAO Rome, Italy.

Guldin, J.M. and Graham, R.T. (2007). Silviculture for $21^{\text {st }}$ century-objective and subjective standards to guide successful practice. USDA Forest Service Gen.Tech.Rep.PSW-GTR-203.

Hanna, K.S., Clark, D.A. and Slocombe, D.S. (2008). Introduction: Protected areas in a changing world. In Transforming parks and protected areas:policy and governance a changing world, Ed. Hanna K,S. Clark, D.A. and D.S. Slocombe. Routledge 270 Madison Avenue, New York,NY 10016. 
IPCC (Intergovernmental Panel on Climate Change). (2007). Climate Change 2007; Mitigation, Contribution of Working Group III to the Fourth Assessment Report of the Intergovernmental Panel on Climate Change, ed. B. Metz, O.R. Davidson, P.R. Bosch, R. Dave, and L.A. Meyer. Cambridge University Press, Cambridge, United Kingdom and New York, NY, USA.

IPCC (Intergovernmental Panel on Climate Change). (2000). Land-use, Land-use Change and Forestry, ed. R.T. Watson, I.R. Noble, B.Bolin, N.H. Ravindranath, D.J. Verardo, and D.J. Dokken. Special report. Cambridge University Press, Cambridge.

Kothari, A. and Lockwood, G.L. (2006). Social context. In Protected Areas Management: A Global Guide, ed. M. Lockwood, G.L. Worboys, and A. Kothari, pp. 41-72. Earthscan in the UK and USA.

Kurttila, M., Pesonen, M., Kangas, J. and Kajanus, M. (2000). Utilizing the analytic hierarchy process AHP in SWOT analysis-a hybrid method and its application to a forest-certification case. Forest Policy and Economics 1:41-52.

Larson, A.M. and Ribot, J.C. (2007). The poverty of forestry policy: double standards on an uneven playing field. Sustainability Science 2:189-204.

Margules, C. and Sarkar, S. (2007). Systematic conservation planning. Cambridge University Press.

Mawapanga, M.N. and Debertin, D.L. (1996). Choosing between alternative farming systems: an application of the analytic hierarchy process. Review of Agricultural Economics 18:385-401.

Ministry of Forestry. (2006). Recognizing 21 national park model in Indonesia. General Directorate of Forestry Protection and Nature Conservation. Ministry of Forestry, Indonesia. http://www.dephut.go.id

Ministry of Forestry, Indonesia. (2004). Ministry of Forestry Decision (SK.134/MENHUT-II/2004). Changing function forest conservation, sanctuary and natural park recreation merapi located at Magelang, Boyolali and Klaten District, Central Java Province and Sleman District, Yogyakarta Province to Gunung Merapi National Park. [online] Available :http://www.dephut.go.id (February 3, 2010)

Mlinsek. (1996). From clear-cutting to close-to-nature silviculture system. International Union Research Organizations, IUFRO News 25 (4):6-8.

Murniati., Garrity, D.P. and Gintings, A.N. (2001). The contribution of agroforestry systems to reducing farmers' dependence on the resources of adjacent national parks: a case study from Sumatra, Indonesia. Agroforestry Systems 52:171-184.

Nair, P.K.R. (1998). Directions in tropical agroforestry research: past, present, and future. Agroforestry Systems 38: 223-245.

O'Hara, K.L. (2001). The silviculture of transformation-a commentary. Forest Ecology and Management 172:291-300.

Parviainen, J. and Frank, G. (2003). Protected forests in Europe approaches-harmonising the definitions for international comparison and forest policy making. Journal of Environmental Management 67:27-36.

Pesonen, M., Kurttila, M., Kangas, J., Kajanus, M. and Heinonen, P. (2000). Assessing the priorities using A_WOT among resource management strategies at the Finish Forest and Park Service. Forest Science 47 (4): 534-541.

Phillips, A. (2003). Turning Ideas on their Head-the New Paradigm for Protected Areas.The George Wright Forum 20 (2):8-32.

Rogers, E.M., Burdge, R.J., Korsching, P.F. and Donnermeyer, J.F. (1988). Social Change in Rural Societies: An Introduction to Rural Sociology. Third edition. Prentice-Hall, Englewood Cliffs, NJ.

Saaty, T.L. and Vargas, L.G. (2001). Models, Methods, Concepts and Applications of the Analytic Hierarchy Process. Kluwer Academic Publishers, Boston, MA.

Saaty, T.L. (1993). The analytic hierarchy process: a 1993 overview. Central European Journal of Operation Research and Economics 2 (2):119-137.

Saaty, T.L. (1977). A scaling method for priorities in hierarchical structure. Journal of Mathematical Psychology 15:234-281.

Sayer, J.A. and Maginnis, S. (2005). New challenges for forest management. In Forest in Lanscapes: Ecosystem approaches to sustainability, ed. J.A. Sayer, and S. Maginnis, pp. 1-16. Earthscan.

Sayer, J.A. (2001). Learning and Adaptation for Forest Conservation. In Biological Diversity: Balanding interest through adaptive collaborative management, ed. L.E. Buck, C.C. Geisler, J. Schelhas, and E. Wollenberg, pp. 69-80.CRC Press.

Scherl, L.M., Wilson, A., Wild, R., Blockhus, J., Franks, P., McNeely, J.A. and McShane, T.O. (2004). Can Protected Areas Contribute to Poverty Reduction? Opportunities and Limitations. IUCN, Gland, Switzerland and Cambridge, UK. 
Snelder, D.J. and Lasco, R.D. (2008). Smallholder tree growing in South and Southeast Asia. In Smallholder tree growing for rural development and environmental services lessons from Asia, ed. D.J. Snelder, and R.D. Lasco, pp. 3-36. Springer.

Suryanto, P., Zaki, M.H., Azmy,M., \& Azani,M.A. (2011). Silviculture Agroforestry Regime: Compatible Management in Southern Gunung Merapi National Park, Java, Indonesia. International Journal of Biology Vol. 3, No. 2, April 2011.

Suryanto, P., Zaki, M.H., Azmy,M., \& Azani,M.A. (2010a). Agroforestry typology and its implications on surrounding South Region of Gunung Merapi National Park, Java, Indonesia. The Malaysian Forester 73, 2, 229-238.

Suryanto, P., Zaki, M.H., Azmy,M., \& Azani,M.A. (2010b). Impact of community intervention on grass stock at Gunung Merapi National Park (Southern), Java, Indonesia. Research in Environmental and Life Science 3(3), 123-132.

Suryanto, P., Zaki, M.H., Azani,M.A., \& Azmy,M. (2010c). Species diversity of Gunung Merapi National Park, Java, Indonesia following 2006 eruption. Research in Environmental and Life Science 3 (1), 1-6.

Suryanto, P., Zaki, M.H., Azani,M.A., \& Azmy,M. (2010d). Post-eruption species dynamic of Gunung Merapi National Park, Java, Indonesia. Journal of Tropical Biology \& Conservation 7:49-57.

Suryanto, P., Zaki, M.H., Azmy,M., \& Azani,M.A. (2010e). The dynamic growth and standing stock of Acacia decurrens following the 2006 eruption in Gunung Merapi National Park, Java, Indonesia. International Journal of Biology 2 (2), 165-170.

World Bank. (2005). 'Agriculture investment note on agroforestry systems', in Sustainable Natural Resource Management for Agriculture, Agriculture Investment Sourcebook: Module 5, World Bank, Washington, DC.

Wishitemi, B.E.L. and Okello, M.M. (2003). Application of the Protected Landscape Model in southern Kenya. Parks Vol 13 No 2 Category V.

Table 1. Factor priority scores and overall priority scores of SWOT-AHP analysis

\begin{tabular}{|l|c|c|c|c|c|c|c|}
\hline \multirow{2}{*}{ SWOT Groups } & \multicolumn{3}{|c|}{ Factor Priority } & \multicolumn{3}{c|}{ Overall Priority } & \multirow{2}{*}{$\begin{array}{c}\text { Mean } \\
\text { Score }\end{array}$} \\
\cline { 2 - 7 } & $\begin{array}{l}\text { Local } \\
\text { community }\end{array}$ & Government & Researcher & $\begin{array}{l}\text { Local } \\
\text { community }\end{array}$ & Government & Researcher & Sc.3463 $^{\mathrm{a}}$ \\
\hline Strengths & & & & $\mathbf{0 . 2 4 7 0}$ & $\mathbf{0 . 4 0 6 3}$ & $\mathbf{0 . 3 8 0 6}$ & $\mathbf{0 . 3 4 4 6}$ \\
S1 & 0.1164 & 0.6518 & 0.4147 & 0.0287 & $\underline{0.2648}$ & $\underline{0.1578}$ & 0.1505 \\
S2 & 0.6291 & 0.1543 & 0.3734 & $\underline{0.1554}$ & 0.0627 & $\underline{0.1421}$ & 0.1201 \\
S3 & 0.2545 & 0.1939 & 0.2120 & 0.0629 & 0.0788 & 0.0807 & 0.0741 \\
Weaknesses & & & & $\mathbf{0 . 1 4 3 9}$ & $\mathbf{0 . 0 7 4 6}$ & $\mathbf{0 . 1 3 4 6}$ & $\mathbf{0 . 1 1 7 7}$ \\
W1 & 0.2819 & 0.2861 & 0.3594 & 0.0406 & 0.0214 & $\underline{0.0484}$ & 0.0368 \\
W2 & 0.2755 & 0.2552 & 0.1869 & 0.0397 & 0.0190 & 0.0252 & 0.0280 \\
W3 & 0.4426 & 0.4587 & 0.4536 & $\underline{0.0637}$ & $\underline{0.0342}$ & $\underline{0.0611}$ & 0.0530 \\
Opportunities & & & & $\mathbf{0 . 3 3 1 3}$ & $\mathbf{0 . 2 7 1 9}$ & $\mathbf{0 . 2 5 7 0}$ & $\mathbf{0 . 2 8 6 7}$ \\
O1 & 0.0860 & 0.1886 & 0.1903 & 0.0285 & 0.0513 & 0.0489 & 0.0429 \\
O2 & 0.5049 & 0.6521 & 0.5365 & $\underline{0.1673}$ & $\underline{0.1773}$ & $\underline{0.1379}$ & 0.1608 \\
O3 & 0.4091 & 0.1593 & 0.2732 & $\underline{0.1355}$ & 0.0433 & 0.0702 & 0.0830 \\
Threats & & & & $\mathbf{0 . 2 7 7 7}$ & $\mathbf{0 . 2 4 7 2}$ & $\mathbf{0 . 2 2 7 8}$ & $\mathbf{0 . 2 5 0 9}$ \\
T1 & 0.7239 & 0.3250 & 0.2930 & $\underline{0.2011}$ & $\underline{0.0804}$ & 0.0667 & 0.1160 \\
T2 & 0.1211 & 0.4031 & 0.4858 & 0.0336 & $\underline{0.0996}$ & $\underline{0.1107}$ & 0.0813 \\
T3 & 0.1551 & 0.2719 & 0.2213 & 0.0431 & 0.0672 & 0.0504 & 0.0536 \\
\hline
\end{tabular}

Note: numbers in bolds are scale parameters (values) of each SWOT group and numbers underlined are highest three factors under respondent categories.

${ }^{a}$ This study assigned equal weight for each respondent to keep the analysis simple. However, different weighting schemes can used to aggregate priority scores across stakeholders (Kangas, 1994; Ananda and Herath, 2003). 


\section{Strengths}

$\mathrm{S}_{1}$. Forest rehabilitation and renewal zonation systems of GMNP that are compatible with agroforestry management on surrounding GMNP as a buffer zone intensive.

$\mathrm{S}_{2}$. Reference implementation of pro poor conservation especially on national park with a win-win solution.

$\mathrm{S}_{3}$. Succession potential from species pioneer (A.decurrens) as a supporting local energy stock and the information species diversity for attracting Merapi lava tour.

Weaknesses
$\mathrm{W}_{1}$. Need more skills of silviculture agroforestry
technique.
technique.

$\mathrm{W}_{2}$. Long-term investment of SAR to objective implementation.

$\mathrm{W}_{3}$. Need more full support from stakeholders.

\section{Opportunities}

O1. Increasing the number of national parks and government support for establishing prospective national park.

O2. Collaborative became important mandate on the management of national parks in Indonesia.

O3. Increasing demand of specific silviculture technique for protected area.

Figure 1. Key SWOT factors influencing SAR: compatible management on Southern GMNP

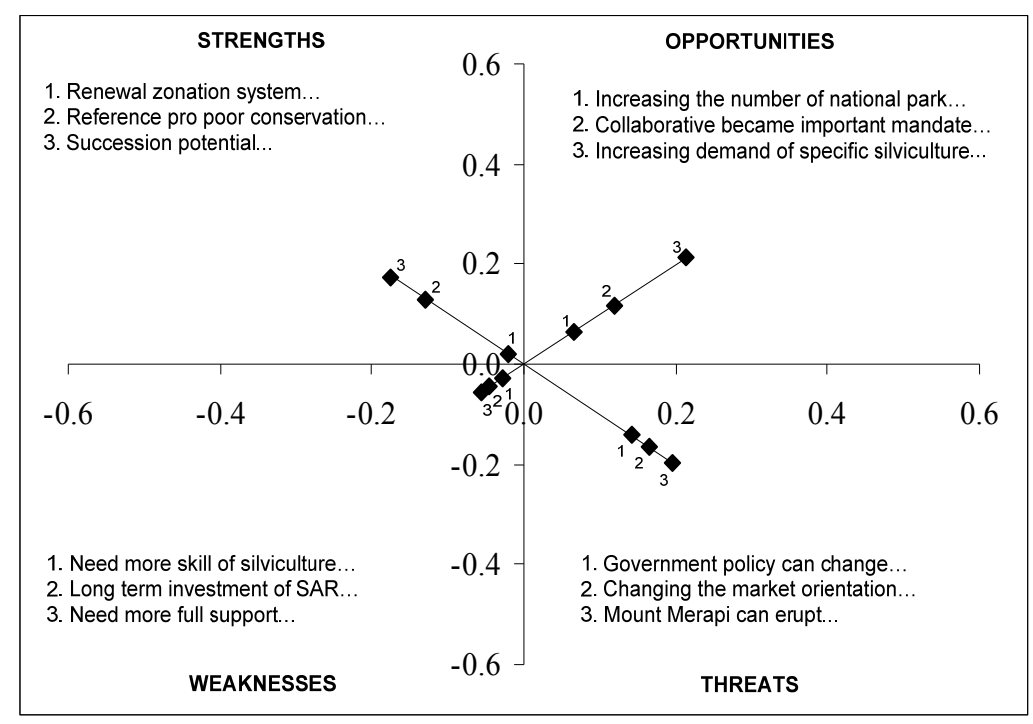

Figure 2 . The local community preferences towards SAR 


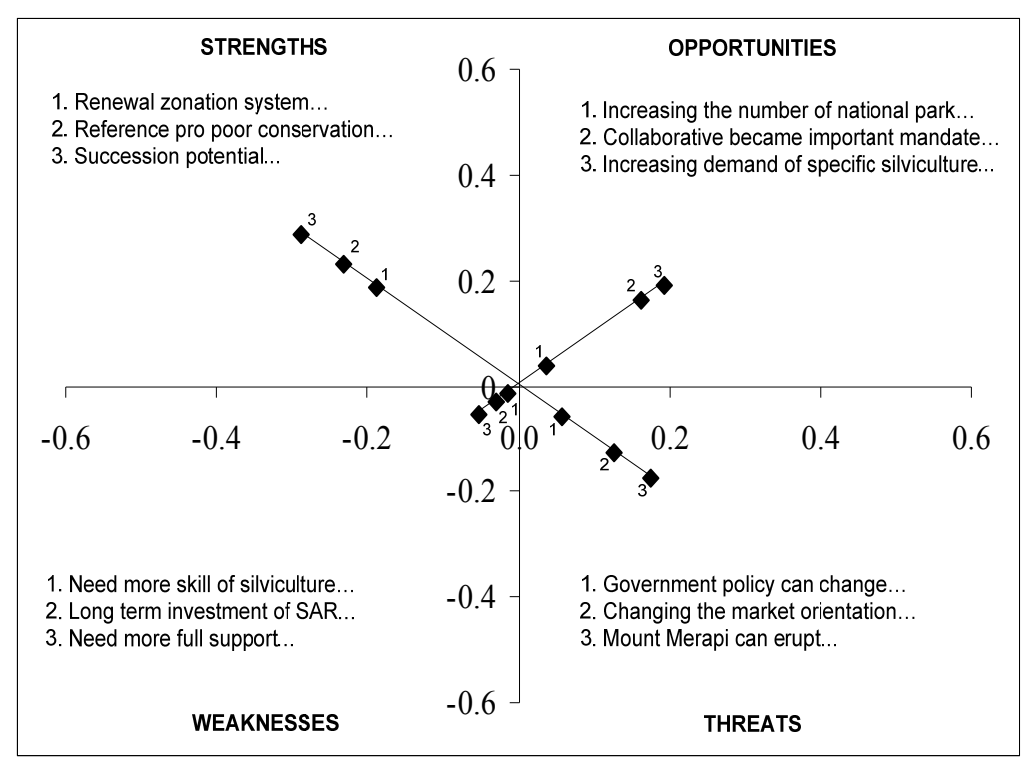

Figure 3. The government preferences towards SAR

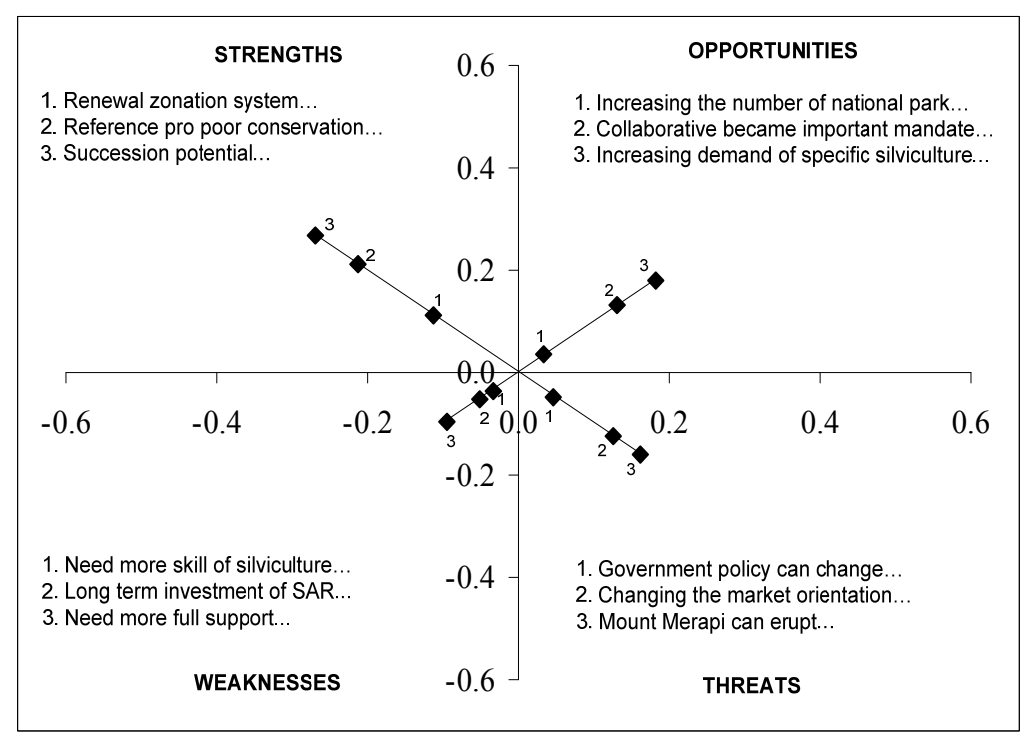

Figure 4. The researcher preferences towards SAR 